\title{
BMPR2 wt Allele
}

National Cancer Institute

\section{Source}

National Cancer Institute. BMPR2 wt Allele. NCI Thesaurus. Code C51729.

Human BMPR2 wild-type allele is located within 2q33-q34 and is approximately $191 \mathrm{~kb}$ in length. This allele, which encodes bone morphogenetic protein receptor type-2 protein, plays a role in endochondral bone formation, signal transduction and embryogenesis. Mutations in this gene have been associated with primary pulmonary hypertension. 